\title{
Differences in basic digital competences between male and female university students of Social Sciences in Spain
}

Open Access

\author{
Esteban Vázquez-Cano ${ }^{1 *}$, Eloy López Meneses² and Eduardo García-Garzón ${ }^{3}$
}

\author{
* Correspondence: \\ evazquez@edu.uned.es \\ ${ }^{1}$ Universidad Nacional de Educación \\ a Distancia, Madrid, Spain \\ Full list of author information is \\ available at the end of the article
}

\begin{abstract}
This article analyses the differences in basic digital competences of male and female university students on Social Education, Social Work and Pedagogy courses. The study of gender differences in university students' acquisition of digital competence has considerable didactic and strategic consequences for the development of these skills. The study was carried out at two public universities in Spain (UNED - the National Distance-Learning University, and the Universidad Pablo de Olavide) on a sample of 923 students, who responded to a questionnaire entitled "University Students' Basic Digital Competences 2.0" (COBADI - registered at the Spanish Patent and Trademark Office). The research applied a quantitative methodology based on a Bayesian approach using multinomial joint distribution as prior distribution. The use of Bayes factors also offers advantages with respect to the use of frequentist $p$-values, like the generation of information on the alternative hypothesis, that the evidence is not dependent on the sample size used. The results show that men have greater perceived competence in digital cartography and online presentations, whereas women prefer to request personal tutorials to resolve doubts about technology and have greater perceived competence in corporate emailing. There is also evidence that the men have greater perceived competence in developing "online presentations" than women do. Regarding to, "Interpersonal competences in the use of ICT at university", we observed that the female students opted for personal sessions with tutors in greater numbers than the male students did.
\end{abstract}

Keywords: Gender differences, Digital competences, University, Bayes factors

\section{Introduction}

Research on the possible differences between male and female university students in their use of technology has boomed since the beginning of the century with the emergence of the Knowledge and Information Society (Nysveen, Pedersen, \& Thorbjørnsen, 2005; Tüfekçi, 2008; OCDE, 2010b; Liaw \& Huang, 2011). At the same time, the classic statistical approaches based on the traditional null hypothesis significance testing (NHST) has often prevented us from discarding the null hypothesis that men and women are equal in terms of perceived competences in technology (which is not the same as accepting the null hypothesis that men and women have the same level of perceived competence). The problem lies in the mathematical impossibility of quantifying exactly how far the evidence supports the hypotheses using NHST and associated $p$-values. $P$-values are not a measure

(c) The Author(s). 2017 Open Access This article is distributed under the terms of the Creative Commons Attribution 4.0 International License (http://creativecommons.org/licenses/by/4.0/), which permits unrestricted use, distribution, and reproduction in any medium, provided you give appropriate credit to the original author(s) and the source, provide a link to the Creative Commons license, and indicate if changes were made. 
of the evidence for or against any hypothesis, nor must they influence decision taking on, for example, developing educational programmes on technology competence that are targeted according to gender (American Statistical Association, 2016).

Besides the "classic" statistics approach, researchers have also used the TAM (Technology Acceptance Model) and UTAUT (Unified Theory of Acceptance and Use of Technology) to measure the gender variable, with diverse results. In this article, we propose using the Bayes factor as an alternative method of analysis to measure how far the data support the hypotheses related to whether there are, or are not, any differences between men and women in their application of technological competences in the university context. Bayesian statistics offer important advantages for the classic null hypothesis inference processes, which include: (a) the generation of information on both hypotheses (the null hypothesis and its alternative); (b) non-dependence on the sample plan or on the researchers' intentions (allowing additional information to be gleaned from the sample without the need to use procedures to maintain any error probability constant (Wagenmakers, 2007); (c) delivering interpretations that are intuitive and easy to understand (and as likely as the data are for each hypothesis).

\section{Bayes factor to analyse gender differences in the use of technology}

The study of the educational differences has been mainly associated with the hypothesis analysis (Ares, 1999; Díaz \& de la Fuente, 2004), but this statistical approach generates numerous problems. For example, interpreting that when we reject the null hypothesis, we get support for the (alternative) research hypothesis is not totally correct, since a significant result does not indicate the magnitude of the effect, so the statistical hypothesis does not report on the significance of data (Hager, 2000; Finch, Cumming, \& Thomason, 2001). The interesting thing about non-categorical issues such as gender differences is to be able to establish the magnitude of the effect. For this reason, the use of Bayesian methods, a subject that has hardly received attention in educational research, is recommended by eminent psychologists and educators such as Edwards, Lindman, and Savage (1963), Rozeboom, Morrison, and Henkel (1970), Pruzek (1997), Rindskopf (1997) and Lecoutre (1996).

A fundamental difference between Bayesian and classical inference is the subjective (and non-frequency) character of the probabilities, since the problem of repeated sampling does not arise and it does not require the concept of sample distribution. Subjective probabilities can be defined for any proposition, while the classical inference is defined only for events in a sample space (O'Hagan \& Forster, 2004). Also, the Bayesian method makes use of all the previous information available, whereas in classical inference this information is not processed. Consequently, the Bayesian interpretation of inference seems to be simpler and more natural than the classical one (Pruzek, 1997), as well as providing a basis for coherent decision-making in situations of uncertainty such as gender differences (Western, 1999). In addition, Bayesian inference provides a totally general method, since its application does not require a particular type of distribution and does not need to deduce the distributions in the sampling (Díaz \& Batanero, 2006). This can produce situations where rejecting a null hypothesis does not provide new information, since the only thing we can deduce by rejecting a hypothesis is that there is an effect, but not in what direction or magnitude (Falk \& Greenbaum, 1995, Lecoutre, 1996). On the contrary, in Bayesian inference we can calculate final probabilities of the 
hypothesis and probabilities that the effect has a certain size (Lindley, 1993). This is fundamental in situations such as research in Education in which the effects are interpretable. In the Bayesian method, we can calculate the probability of a future event, by means of the predictive distribution given in the denominator of the Bayes formula, that is, the weighted average of the likelihood function, weighted by the initial probabilities (Berry, 1995). Furthermore, in the Bayesian framework it is conceivable a sequence of articulated experiments where the information of each is incorporated into the next one (Pruzek, 1997).

Today the development of digital competences is seen as a crucial part of university students' education. Students today must be competent in the use of specific codes, symbol systems and forms of interacting with digital information, and all this via the communication networks (Aguaded \& Cabero, 2013; Area, 2014). Autonomy is fundamental for students to enable them to classify the information that "bombards" them from the media and the new information technologies. Teachers need to develop this capacity in their students; teaching should not be the mere transmission of knowledge but should aim to equip a person to become both an autonomous and social being. Teachers must be competent enough to carry out an activity as crucial as forming other human beings (OCDE, 2010a). The study of gender differences in university students' acquisition of digital competence is important in that it can help us to understand how male and female students engage with basic digital competences; it also has considerable didactic and strategic consequences for the development of these skills. Three models have been used for researching gender differences in technology use: the "classic" statistical model that is fundamental to the null hypothesis inference process; TAM, based on three factors: perception of ease of use, perceived usefulness and behavioural intention regarding the use of the system with the inclusion of the gender variable; UTAUT, which codifies four key determinants of acceptance and use: performance expectation, effort expectation, social influence and facilitating conditions, which are moderated by gender, age, experience and voluntariness of use, which refers to whether the use of the technology is voluntary or involuntary (Venkatesh, Morris, Davis, \& Davis, 2003).

The literature on the "classic" statistical analysis approach so far this century has highlighted gender differences in Internet use and online reading preferences that point to superior male competence (Liu \& Huang, 2008). Hupfer and Detlor (2006) found that men bettered women in demonstrating greater competence in online information search processes. Other research by Garbarino and Strahilevitz (2004) showed that the Internet is mainly used to build on already existing relationships. Furthermore, PISA test results have revealed interesting differences between the digital skills of male and female students. Women tend to read more, both in print and digital versions, than men do; however, the gender gap is narrower in the later (OCDE, 2010b). Rajagopal and Bojin (2003) found significant differences of more than eight percentage points between male and female university students in web page creation competence. Likewise, a study using a t-test of two groups totalling 3309 students at California State University found significant differences between men and women, with the former outperforming in information search with different search engines, assembling components, and in efficient and appropriate access to information to resolve problems and using "pirate software" (Liu \& Sun, 2012). "Classic" statistical approaches have produced studies on gender differences in the use of 
social networks (Tüfekçi, 2008; Mazman \& Yasemin, 2011), with the results showing that women use Facebook, for example, to maintain pre-existing relationships or for academic purposes, while men use social networks to form new relationships. In Spain, recent research that sampled 493 university students found no significant gender differences in the use of mobile digital devices (Vázquez-Cano, 2014; Sevillano \& Vázquez-Cano, 2015), and studies that assessed students' digital linguistic competence in microblogging found no significant differences between males and females (Vázquez-Cano, 2012; Vázquez-Cano, Mengual-Andrés, \& Roig-Vila, 2015).

On the other hand, evidence was found that female students excelled in having greater strategic competence in online information search than males, in studies on high school teenagers (Vázquez-Cano, López Meneses, \& Sáez López, 2016). Yet such gender differences did not show up in Spanish university students who study Social Science degree courses when they developed online resources created with technological tools (Fernández-Márquez, Vázquez-Cano, \& López Meneses, 2016). Nysveen et al. (2005) used the UTAUT model in a study in Norway to show that men perceived mobile phone chat services to be very useful. Venkatesh and Morris (2000) used TAM on 342 workers and found that the women tended to use technology that required less effort. The study also associated a lower perception of "ease of use" to women, and higher levels of anxiety when using technology. Venkatesh et al. (2003) showed that women were more willing to accept suggestions from work colleagues, which highlights their greater openness to social influence when using technology. The results from a study by Jackson, Ervin, Gardner, and Ervin (2001) of 630 pre-university AngloAmerican students showed that females used email more than males, while the latter made more use of the Internet. The female students in this study demonstrated that they were more nervous about using technology than males, and were less competent in the use of computer hardware. Li and Kirkup (2007) studied 200 Chinese and 245 British students, and concluded that the males used email, online chat rooms and games on the computer more than females, and they also declared a higher level of perception of their digital competence. Nysveen et al. (2005) stated that social influence is more evident in females when using mobile chat services.

Researchers such as Goswami and Dutta (2016) used TAM to investigate possible gender differences in e-learning. Okazaki and Renda dos Santos (2012) sampled 446 Brazilian teachers on the adoption of digital tools in teaching and found that the results were statistically significant for men in three areas: ease of use and perception of usefulness; perception of usefulness and attitude; and intention and current behaviour. Ong and Lai (2006) interviewed 67 women and 89 men at six international companies in Taiwan, and found that the women gave more importance to ease of use digital tools than the men, who in turn appreciated more the usefulness of digital tools for learning. Islam, Abdul Rahim, Chee Liang, and Momtaz (2011) observed gender differences in 80 Malay university students in which the women scored higher than the men when faced with technical barriers in e-learning systems. Liaw and Huang (2011) analysed a sample of 424 university students in Singapore, and concluded that the men were more inclined towards e-learning than the women. Their study also included 200 pre-university students, in which the females had less perception of use of Virtual Learning Environments (VLE) than the males. However, Raman, Rozalina Khalid, and Rizuan (2014) found no differences between males and females when using the Moodle platform, in a sample of 65 Malay university students. Neither did they find that 
gender was significant in determining greater expectation of use, effort expectation, social influence or intention to use. Similar results were found by Suri and Sharma (2013) in India, and other studies have shown that women have a greater predisposition towards, and positive awareness of, the use of technology. Egbo, Chinwe, Ikechukwu, and Onwumere (2011) studied 415 pre-university students in Nigeria and found that the females were more inclined towards technological devices than their male counterparts were.

As the literature shows, there are studies that confirm and refute that there are significant differences between males and females in the use of technology; but there has been no study on whether such differences exist in terms of the basic digital competences that a student can employ throughout his/her university life and later in the job market. The reason for focusing the study in the area of Social Sciences is that degrees such as Social Education, Social Work and Pedagogy share three generic competences based on technology that are common to all subjects (1) Competence in the use of ICT resources. (2) Competence in the search for relevant information and (3) Competence in the management and organization of information. Therefore, our study aims to determine whether through Bayes factor method, we can attribute significant differences in basic digital competences to first-year male and female university students studying Social Sciences courses, specifically Social Education, Social Work and Pedagogy, in Spain.

\section{Method}

\section{Participants}

A total of 923 students responded to the COBADI 2.0 questionnaire (Table 1). The sample consisted mainly of women (81.2\%), young (median age $=22.24(5.2)$, $\mathrm{min} .=17$, max. $=50)$, and in their first year at university $(50.2 \%)$. Bayesian inference allows us to analyze inequitable samples with respect to gender since it allows the addition of new data for coding in the future. The questionnaire was delivered digitally to students studying Social Education and Social Work (Universidad Pablo de Olavide) and Pedagogy (UNED) in academic years 2014/15 and 2015/16. There were no restrictions on participation, and no financial or academic incentive was offered to take part in this study.

\section{Instrument}

The "University Students' Basic Digital Competences 2.0" (COBADI - registered at the Spanish Patent and Trademark Office, http://cort.as/gNom) questionnaire focuses on

Table 1 Descriptive statistics of the sample

\begin{tabular}{lll}
\hline Variables & Sample (923 male/female students) & Percentage \\
\hline Gender & Women & $81.2 \%$ \\
Age & $22.24(5.2)$ & \\
Academic year & $2014 / 15$ & $50.2 \%$ \\
& $2015 / 16$ & $49.8 \%$ \\
University & Universidad Pablo de Olavide & $79.9 \%$ \\
& UNED & $20.1 \%$ \\
Course & Social Education & $47.2 \%$ \\
& Social Work & $32.7 \%$ \\
& Pedagogy & $20.1 \%$ \\
\hline
\end{tabular}


questions related to basic digital competences. It contains 23 items divided in three modules. The first, "Competences in the use of ICT for the search and treatment of information", consists of 11 items measured on a Likert scale of 1-4 points, 1 being "I feel completely ineffective", and 4, "I feel completely in control". This refers to individual competence in the use of various technological tools (e.g. "I know how to use programs to plan my study time (Google Calendar, etc.)". The second module, "Interpersonal competences in the use of ICT at university" has 4 items classified on a 1-4 point Likert scale that refer to how a student resolves his/her ICT doubts and problems, for example, "I contact the teacher online"). In "Doubts about the use of an online university service previously presented and explained in class" ( 4 items on a preference scale according to the use of their content, A-D), this item refers to how the students resolve their difficulties with digital platforms previously presented and explained to the students in class (e.g. "I wait and then I request a personal tutorial with the teacher"). The third module, "Virtual and social communication tools at university" formed of 4 items on a 1-4 point Likert scale, asked the students about their use of the university's own electronic platforms (e.g. "I use the university's email service"). The questionnaire also solicited sociodemographic information on age, gender, degree course, etc.) and on habits of use of online platforms (time spent online, activity, acquisition of electronic material, etc.).

\section{Analysis}

The statistical analysis described how the students perceived their capacity in terms of the COBADI modules, by checking which platforms and media for seeking assistance they felt most competent to use. We checked to see if these results were the same for male and female students, and between students of different courses and universities. This analysis was carried out using the JASP program and the Bayes factor package (Morey \& Rouder, 2015) of the R statistical software program (R Development Core Team). The gender differences were analysed, as in other studies, by t-test techniques, and the Bayes factors (Rouder, Speckman, Sun, Morey, \& Iverson, 2009) were used for the Bayesian analysis of variance (ANOVA). The preference scales analysis was done by a Bayesian analysis of contingency tables in the line of Tahira Jamil, Morey, Love, Marsman, and Wagenmakers (2017), using a joint multinomial distribution as prior distribution. In the analyses, the Likert scale responses were treated as an interval scale, and as continually distributed (Lubke \& Muthen, 2004; Richards, Magee, \& Artino, 2012). A Bayes factor consists of a ratio that contrasts the plausibility of data under a null hypothesis (in this case, the absence of any difference between male and female university students, or between students of different faculties in an item) and the alternative hypothesis (Jarosz \& Wiley, 2014). The use of Bayes factors also offers advantages with respect to the use of frequentist $p$-values, like the generation of information on the alternative hypothesis, that the evidence is not dependent on the sample size used (Wagenmakers, 2007; Dienes, 2011; Wetzels et al., 2011; Rouder \& Morey, 2012), and the delivery of interpretations that are intuitive and easy to understand. In contrast, the calculation of the Bayes factors means taking into account possible prior information on the potential values that the size of the effect can have. In this case, we used a Cauchy distribution as prior distribution, with an $r=1$ parameter (Rouder et al., 2009; Rouder \& Morey, 2012; Wagenmakers et al., 2015), which is similar to a normal 
distribution but with added uncertainty in the tails of the distribution (a greater width of distribution). The $r$ parameter accurately regulates this distribution width. To check how the choice of this parameter affects the final decision taken, we calculated the robustness of the conclusions in various $r$ parameter values. We used the Jeffreys and Raftery classification proposals (Jarosz \& Wiley, 2014) to gain a clearer interpretation of the Bayes factors, by employing the inverse of the Bayes factor (the ratio between the evidence in favour of the alternative hypothesis and the evidence in favour of the null hypothesis), which is presented in Table 2.

\section{Results}

With the George and Mallery (2003) classification, we found that the questionnaire had a high degree of overall reliability ( $\alpha$ Cronbach $=.83(.81-.85)$, Guttman's $\lambda 6=.86)$. We also found a high degree of reliability in the subscale "Competences in the use of ICT for the search and treatment of information" $(\alpha$ Cronbach $=.85$ (.85-.89), Guttman's $\lambda 6=.87$ ), moderate reliability in the subscale "Interpersonal competences in the use of ICT at university" (not considering items based on a preference scale, $\alpha$ Cronbach $=.65$ (.58-.7), $\lambda 6$ Guttman's $\lambda 6=.59$ ), and moderate reliability in the scale "Virtual and social communication tools at university" ( $\alpha_{\text {Cronbach }}=.62(.56-.68)$, Guttman's $\left.\lambda 6=.51\right)$. In addition, no item produced evidence of variance heterogeneity between the sexes. The general descriptive results show (Table 3 ) that the vast majority of students have access to an Internet connection (98.2\%). The time spent on the Internet is distributed among the following activities: university work (68.3\%), use of social networks $(63.9 \%)$ and listening to music (53.3\%). It is significant that $77.8 \%$ stated that they never use Internet for gaming online, and $50.1 \%$ never use it to make new friends.

In the results for "Competences in the use of ICT for the search and treatment of information", we observe that both male and female students feel they have a good level of competence in the use of "search engines", "web browsers", "digital cartography" and "podcasting". The tools they use with less assurance are "QR codes" and the creation of "online presentations". Gender difference was apparent in the use of "digital cartography", with a Bayes factor of 234.30, which indicates that the data are 234.30 times more likely to appear in the hypothesis that states there is a difference between male and female students than in the hypothesis of equal competence between the sexes. This shows that is very strong or decisive evidence in favour of a difference between males and females, with a size of effect of .34 $(.17, .51)$. Therefore, there is evidence that the male students have greater perceived competence in digital cartography than the female students. This effect

Table 2 Interpretation of the Bayes factors regarding evidence for the alternative hypothesis

\begin{tabular}{lll}
\hline Support for the Alternative Hypothesis & & \\
\hline Inverse of the Bayes factor & Raftery & Jeffreys \\
$1-3$ & Weak & Anecdotal \\
$3-10$ & Positive & Substantial \\
$10-20$ & Positive & Strong \\
$20-30$ & Strong & Strong \\
$30-100$ & Strong & Very Strong \\
$100-150$ & Strong & Decisive \\
$>150$ & Very Strong & Decisive \\
\hline
\end{tabular}


Table 3 Connection, activities and time spent on Internet

\begin{tabular}{ll}
\hline Activities & Percentage of time spent \\
\hline Connection to Internet & $98.2 \%$ \\
Time spent & $1-3 \mathrm{~h} \mathrm{(54.2 \% )}$ \\
Surfing on Internet & More than $9 \mathrm{~h}(45.4 \%)$ \\
& Little - Less than $5 \mathrm{~h} /$ week (49.3\%) \\
Watching TV & A lot - More than $6 \mathrm{~h} /$ week (41\%) \\
& A lot - More than $6 \mathrm{~h} /$ week (53.3\%) \\
Listening to music & Never - (77.8\%) \\
Online gaming & A lot - More than $6 \mathrm{~h} /$ week (68.3\%). \\
University work & Little - Less than $5 \mathrm{~h} /$ week (60.2\%) \\
Posting photos and videos & Little - Less than $5 \mathrm{~h} /$ week (53.4\%) \\
Downloading music or films & A lot - More than $6 \mathrm{~h} /$ week (63.9\%). \\
Use of social networks & Never - (50.1\%) \\
Making new friends & Little - Less than $5 \mathrm{~h} /$ week (53.2\%) \\
Group work &
\end{tabular}

was sustained with the inclusion of a prior distribution with an $r$ parameter of 1.5 (Bayes factor $=175.37$, very strong or decisive evidence). In terms of competence in "online presentations", the results show a Bayes factor of 7.29, which indicates that the data are 7.29 times more likely to appear in the hypothesis that there is a difference between male and female students than in the hypothesis of equal competence between the sexes. This shows that there is positive or substantial evidence of a difference between the male and female students, with a size of effect of .28 $(.10, .45)$. Therefore, there is evidence that the men have greater perceived competence in developing "online presentations" than the women. This effect was sustained when including a prior distribution with an $r$ parameter of 1.5 (Bayes factor $=5.36$ ), as shown in Fig. 1 .

In "Interpersonal competences in the use of ICT at university", we observed that the male and female students showed greater "interpersonal competences" when they resorted to their peers at university than when deciding to wait and ask for a meeting with their tutor. We found no differences between men or women in any of the four categories surveyed (Fig. 2).

In "Interpersonal competences in the use of ICT at university", we observed in "doubts about the use of an online university service already presented and explained in class" that the male and female students tend to turn to their colleagues and consult tutorials rather than go to see teachers or request a personal meeting with a tutor when they have doubts about ICT. Figure 3 shows that this trend is sustained in the analysis of the first and second preference. We observed that there were differences regarding seeing a tutor to resolve doubts, with a Bayes factor of 4.50, which indicates that the data are 4.5 times more likely in the hypothesis that there is a difference between men and women than in the hypothesis of equal preference. The female students tend to prefer to see their tutors to resolve doubts about technology more than the male students do. There was no evidence of any other difference between the sexes.

In "Virtual and social communication tools at university", we observed that the male and female students had greater competence in the use of online platforms and the university email service than in the use of the daily planner or university social networks 


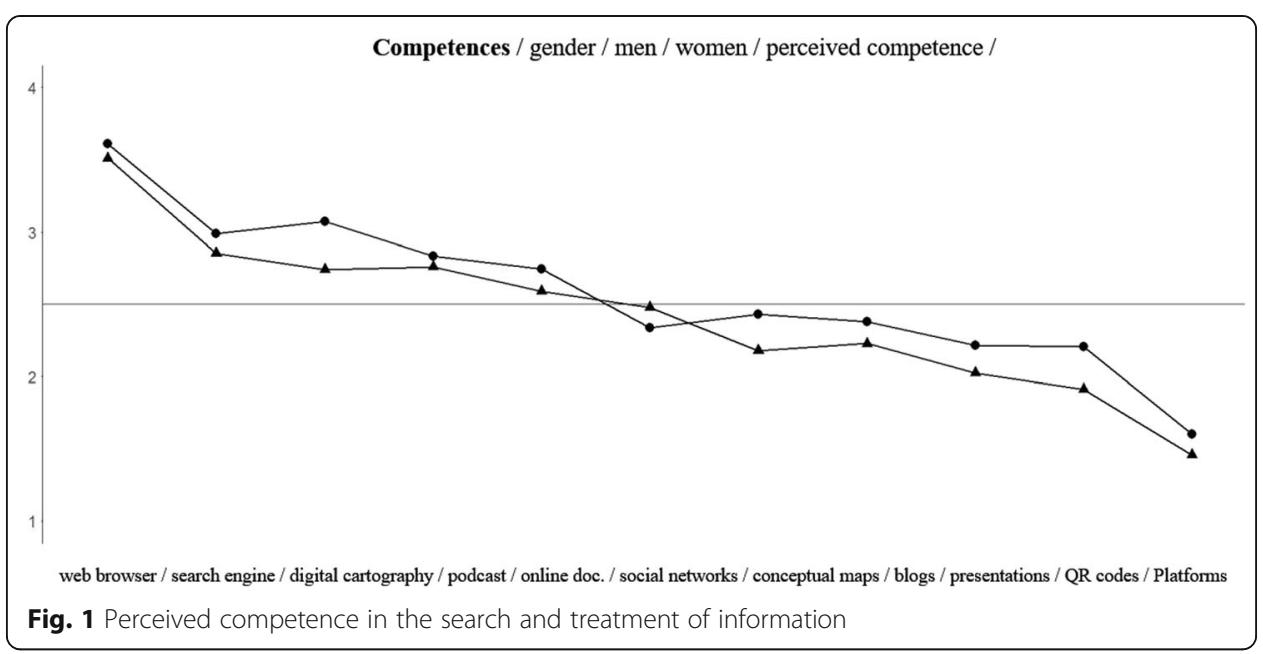

(Fig. 4). We also observed differences between them in perceived competence in the use of "university email", which had a Bayes factor of 12.55. This indicates that the data were 12.55 times more likely to appear in the hypothesis that there is a difference between men and women than in the hypothesis of equal competence. This shows that there is positive or substantial evidence of a difference between men and women, with a size of effect of $-.26(-.43,-.1)$. Therefore, there is evidence that the men have less perceived competence in the use of university email than the women. This effect was sustained when including a prior distribution with an $r$ parameter of 1.5 (Bayes factor $=6.95)$.

In "Competences in the use of ICT for the search and treatment of information", the results showed that the students feel they have a good level of competence in the use of web browsers, search engines and cartography. The tools that students feel less competent to use were the "QR codes", "online presentations" and "use of blogs". Table 4 presents the main evidence gathered on the students on Social Sciences courses from the participating universities; the results show that students at Pablo de Olavide (UPO in the table) tend to feel insecure about their competence to use "digital cartography" and "university social networks", while UNED students stand out in their "competence in social networks" and use of "web browsers".

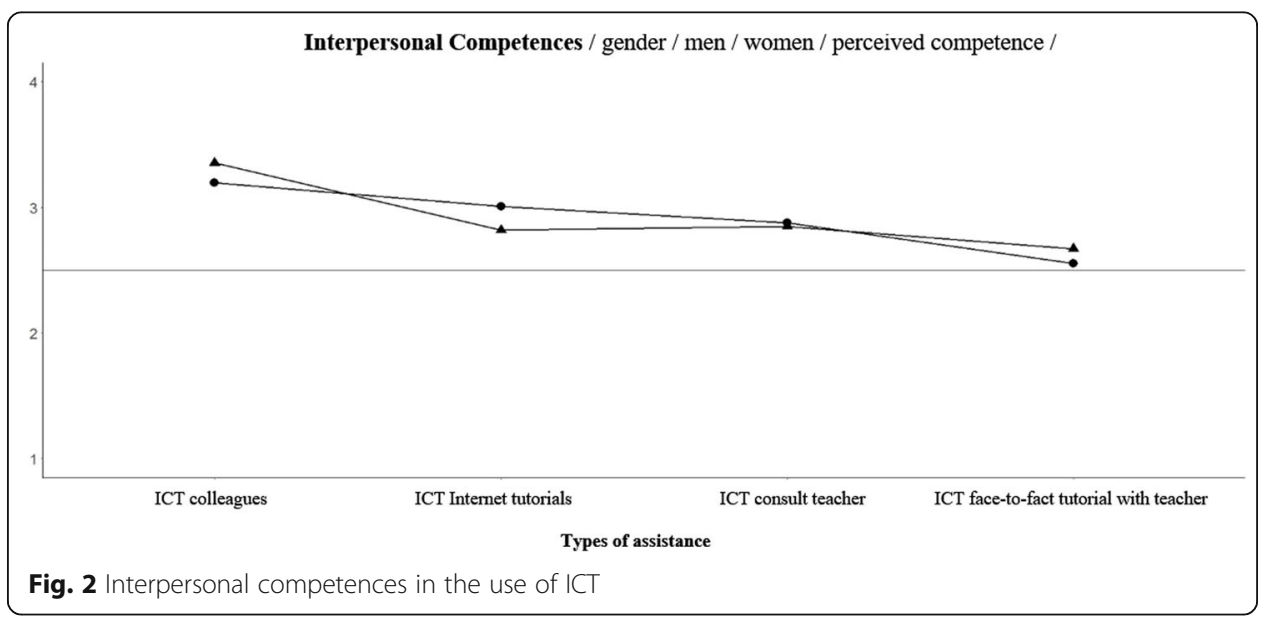




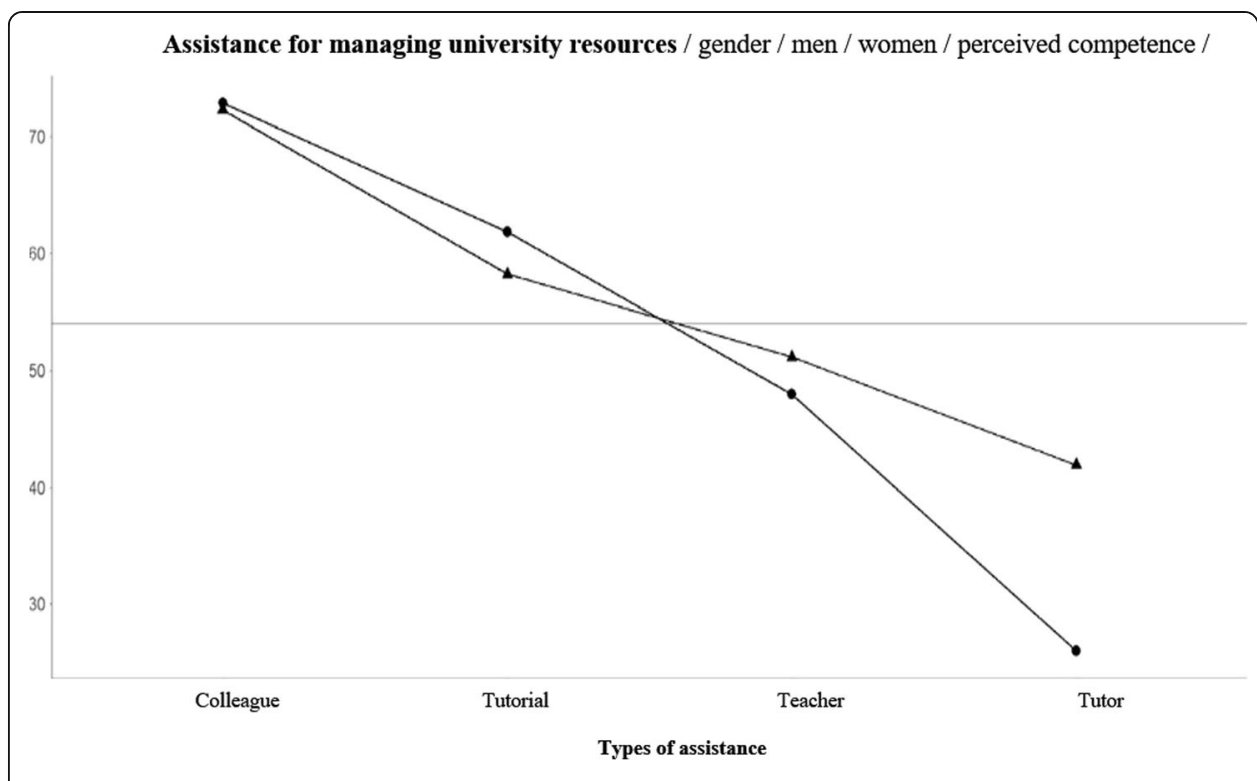

Fig. 3 Interpersonal competences on the use of an online university service presented and explained in class

With regard to "Interpersonal competences in the use of ICT at university", we observed in "interpersonal competences" that the students of both universities showed greater interpersonal competence when turning to their peers and less competence when deciding to wait and request a personal tutorial with a teacher. Students from UNED showed less competence than those at Pablo de Olavide when deciding to "express their doubts to a professor-tutor", although they displayed more competence in the use of "Internet tutorials" (Fig. 5).

In the analysis of "Interpersonal competences in the use of ICT at university", we observed in "doubts about the use of an online university service already presented and explained in class" that both men and women tend to turn to colleagues and tutorial material rather than to teachers or to request a tutorial with a teacher when they have doubts about ICT at university. Figure 6 shows that this trend remained unchanged when we analysed first and second preference choices. We carried out a Bayesian

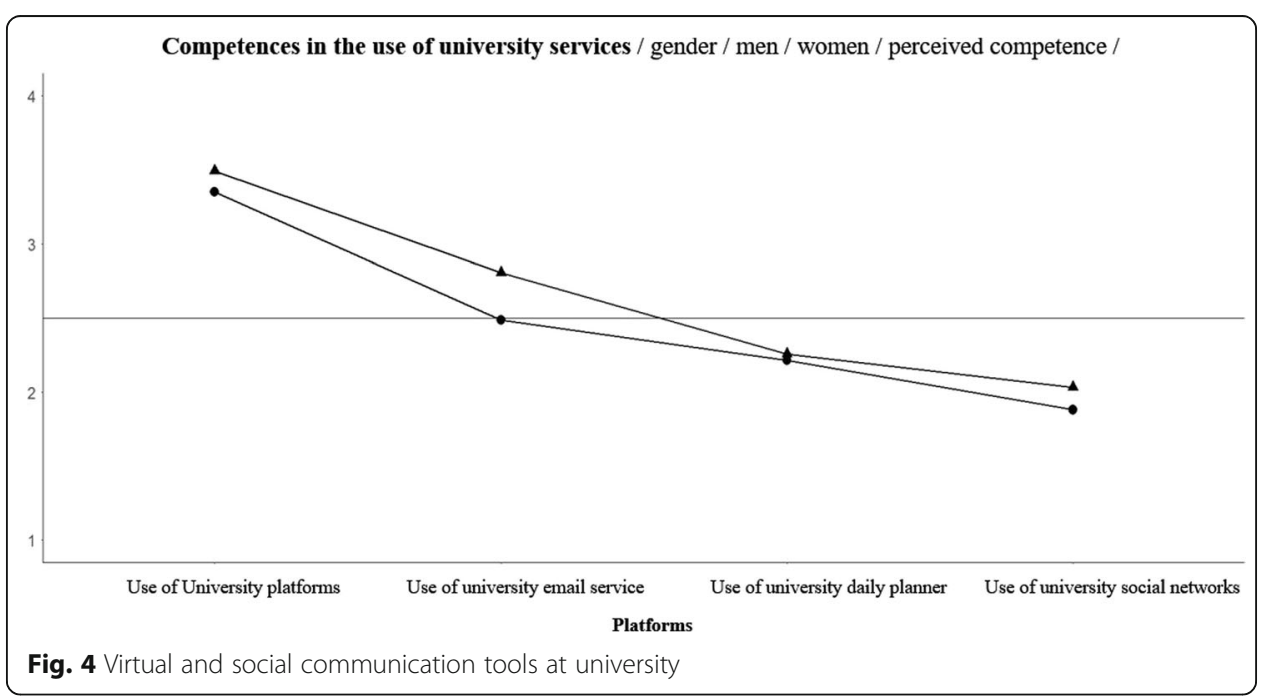


Table 4 Competences compared between the two universities in ICT use in the search and treatment of information

\begin{tabular}{|c|c|c|c|c|}
\hline University & Module & & Bayes factor & Size of effect \\
\hline \multirow[t]{2}{*}{ UPO } & ICT competence & Online cartography & 20.22 & $-.23(-.36,-.1)$ \\
\hline & & Use of university social networks & 47.61 & $-.26(-.41,-.12)$ \\
\hline UPO & ICT competence & Social networks & 106.72 & $-.32(-.46,-.18)$ \\
\hline \multirow[t]{2}{*}{ UNED } & ICT competence & Social networks & 6.67 & $.35(.1, .65)$ \\
\hline & Interpersonal competence & Professor & 4.66 & $-.35(-.59,0.07)$ \\
\hline \multirow[t]{5}{*}{ UNED } & ICT competence & Web browsers & 179.81 & $.26(.14, .4)$ \\
\hline & & Social networks & 106.72 & $-.32(-.46,-.18)$ \\
\hline & Interpersonal competence & Internet tutorial & 16.729 & $.22(.36, .10)$ \\
\hline & University tools & Use of university email & 21.21 & $-.23(-.37,-.09)$ \\
\hline & University tools & Use of university social networks & 90.09 & $-.30(-.44,-.16)$ \\
\hline
\end{tabular}

analysis of contingency tables in the line of Jamil et al. (2015), using a joint multinomial distribution as distribution.

We observed that there were differences in terms of resorting to face-to-face tutorials to resolve ICT doubts, with a Bayes factor of 4.50. This indicates that the data are 4.5 times more likely in the hypothesis that there is a difference between men and women than in the equal preference hypothesis. Women tend to prefer attending tutorials with a teacher than men do. We found no evidence of any other gender differences.

In the use of "Virtual and social communication tools at university", we observed that both men and women showed greater competence in the use of "online university platforms" than in the use of the "daily planner or university social networks" (Fig. 7). We only noticed differences between them in perceived competence in the use of "university email", where there was a Bayes factor of 12.55 , meaning that the data were 12.55 times more likely in the hypothesis of differences between men and women than in the hypothesis of equal competence, with a size of effect of $-.26(-.43,-.1)$. Therefore, there is evidence that the male students have less perceived competence in the use of

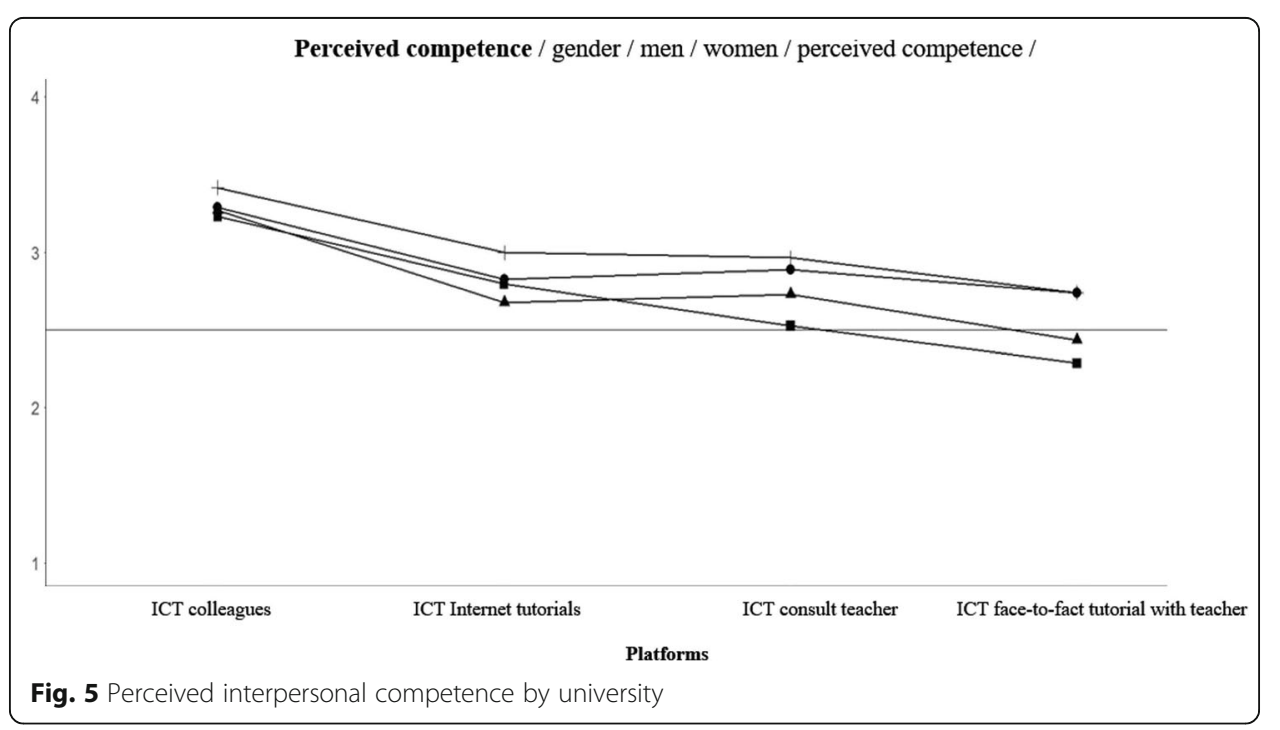




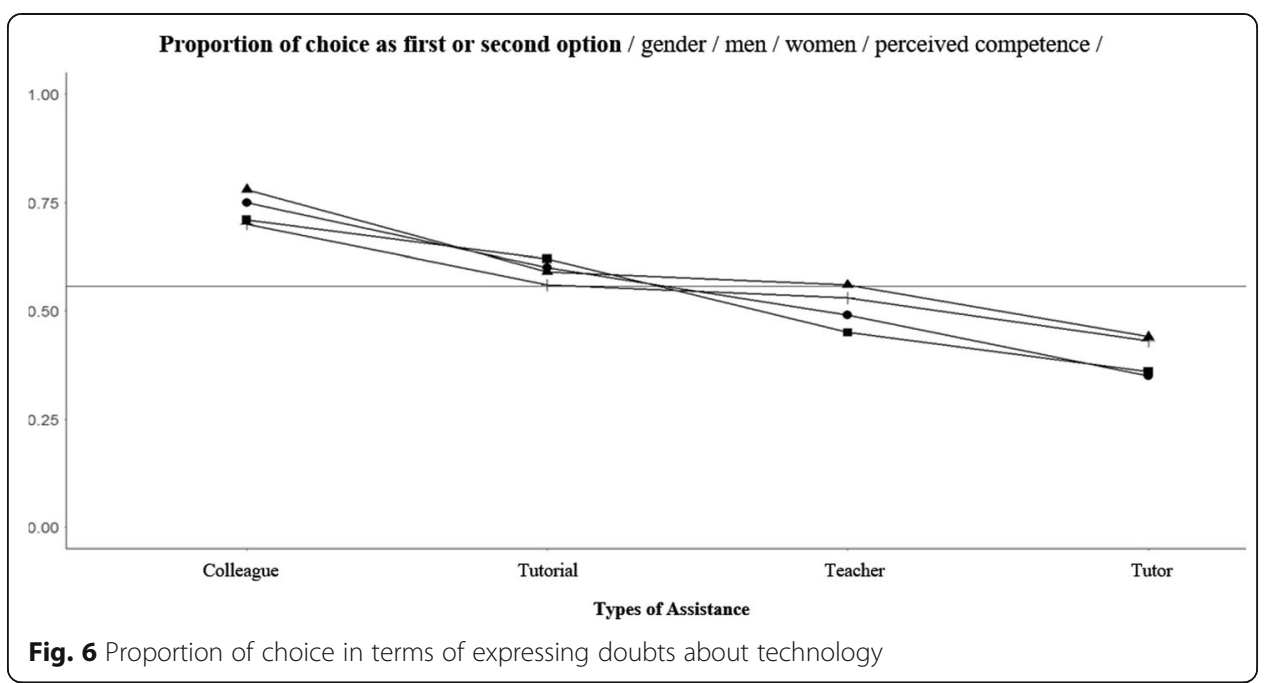

university email than the women do. This effect was sustained when we included a prior distribution with an $r$ parameter of 1.5 (Bayes factor $=6.95$ ).

\section{Discussion and conclusions}

This study was designed to determine possible differences in basic digital competences between male and female university students on Social Sciences (Social Education, Social Work and Pedagogy) courses at a distance-learning university (UNED) and a public full-time attendance university (Pablo de Olavide) in Spain. The results for "Competences in the use of ICT for the search and treatment of information" show that both men and women feel they have a good level of competence in the use of "search engines", "web browsers", "digital cartography" and "podcasting". In terms of the first module, "Competences in the use of ICT for the search and treatment of information", the results show that the male students have greater perceived competence in "digital cartography" than the female students do. This effect was sustained when we included a prior distribution with an $r$ parameter of 1.5 (Bayes factor $=175.37$, which indicates very strong or decisive evidence). These results are in line with classic statistical studies, in which men show greater competence in online information search processes than women (Hupfer \& Detlor, 2006; Liu \& Sun, 2012).

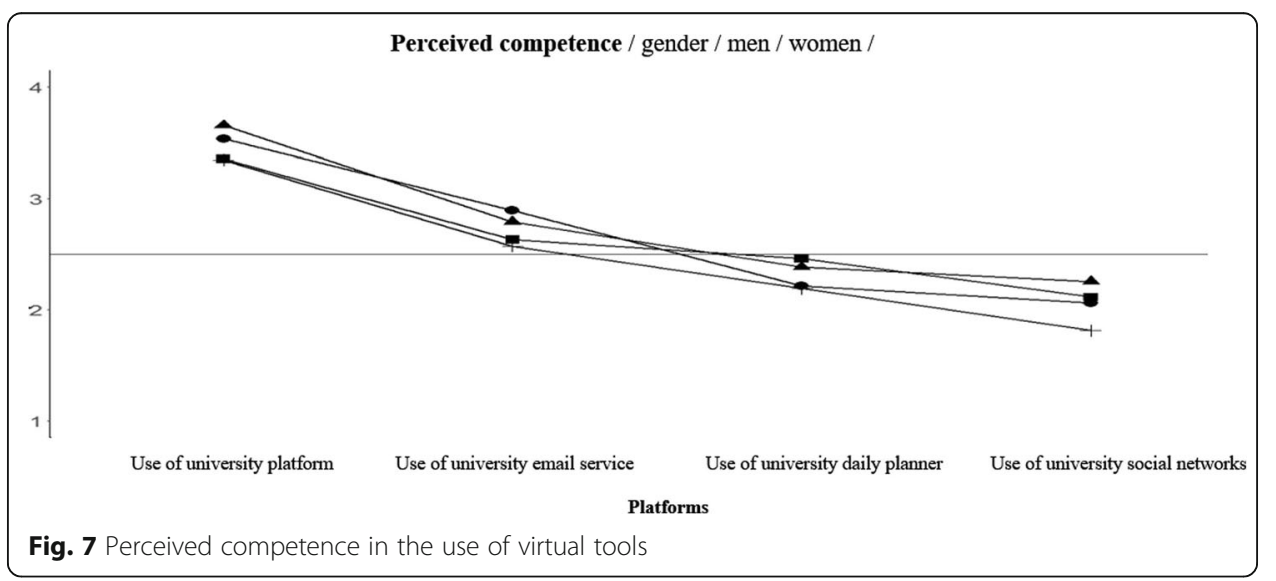


There is also evidence that the men have greater perceived competence in developing "online presentations" than women do. This effect continued when we included a prior distribution with an $r$ parameter of 1.5 (Bayes factor $=5.36$ ). Our results do not corroborate those in other studies in which no evidence was found of a significant gender difference in the use of technological resources for content presentation (Fernández-Márquez et al., 2016).

The analysis of the second module, "Interpersonal competences in the use of ICT at university", showed that both men and women felt they had good interpersonal competence when they "turned to their peers" for assistance, but were less self-assured when "deciding to wait and ask for a tutorial with a teacher". No gender differences were found in any of the four categories surveyed. In contrast, when interpersonal competence is related to a university service that has previously been presented and explained, we observed that the female students opted for personal sessions with tutors in greater numbers than the male students did (Bayes factor $=4.50$ ). These findings are partially reflected in other studies (Islam et al., 2011) in which the women showed more competence than men in overcoming technical obstacles in e-learning systems.

In the analysis of the third module, "Virtual and social communication tools at university", we observed that both men and women showed greater competence in the "use of online platforms" and "university email" than in the use of the "daily planner or university social networks". We only found differences between the sexes in perceived competence in the use of "university email", where there was a Bayes factor of 12.55, which indicates positive or substantial evidence of a difference between men and women, with a size of effect of $-.26(-.43,-.1)$. Therefore, there is evidence that men have greater perceived competence in the use of university email than women do, and this effect was sustained when including a prior distribution with an $r$ parameter of 1.5 (Bayes factor $=6.95)$. These findings match others which, since the start of the century, have found that women are more willing to use email. Jackson et al. (2001) studied 630 pre-university Anglo-American students and found that the women used email more than the men did.

The differences between the distance-learning and full-time attendance formats of university revealed that the students of the latter, at Universidad Pablo de Olavide, do not feel competent in the use of "digital cartography" or "use of university social networks", whereas UNED students positively stand out in "competence in social networks" and in the use of "web browsers". This could be due to the heavier use in distance learning of teaching-learning platforms that function in similar ways to social networks in their use of walls, forums and messaging services.

Finally, the results of this investigation are tempered by certain limitations mainly due to the questionnaire used. The variables and the macro-categories applied to search for gender differences in the use of technology should be standardised for general use within any social-educational context in order to be able to establish divergences and convergences within the same interpretative framework.

Redressing gender equalities as a matter of equal rights is not the only reason for addressing gender related issues in ICT; there is also a clear economic case for promoting gender equality. Gender equality in science, technology, and innovation is not simply a matter of fairness. A more equitable gender balance is believed to enhance the recruitment of the most talented, irrespective of gender (European Commission, 2008). Until now, technological change, especially when it is designed to improve the quality of life, has been 
more directed to the tasks that men perform, than to those performed by women, both in and outside the home. In turn, an absence of women in decision-making positions within the media sector, including on governing boards and bodies (both in the government and private sector) that influence media policy, contributes to perpetuating this vicious circle of negative gender stereotypes. As you can see in the results of this research, there is still a greater digital competence perceived by men in certain digital skills, although the subsequent materialization of this competition does not show differences in performance between men and women. As recent studies establish, the paucity of sex-disaggregated ICT data, particularly from developing countries, makes it difficult, if not impossible, to make the case to policymakers for their consideration of gender-related issues in ICT policies, plans and strategies (United Nations, 2014). The lack of adequate data resulting from the scarcity of gender statistics affects policy and its implementation. Thus, this study can enable a better understanding of the different ways in which men and women experience ICTs at University and would present a more accurate picture of the scope and intensity of the gender-based digital divide from a robust methodological approach.

Authors' contributions

All authors read and approved the final manuscript.

Competing interests

The author(s) declare(s) that they have no competing interests.

\section{Publisher's note}

Springer Nature remains neutral with regard to jurisdictional claims in published maps and institutional affiliations.

\section{Author details}

${ }^{1}$ Universidad Nacional de Educación a Distancia, Madrid, Spain. ${ }^{2}$ Universidad Pablo de Olavide, Sevilla, Spain.

${ }^{3}$ Universidad Autónoma de Madrid, Madrid, Spain.

Received: 30 March 2017 Accepted: 19 June 2017

Published online: 07 November 2017

\section{References}

Aguaded I., \& Cabero J. (2013). Tecnologías y medios para la educación en la e-sociedad (). Madrid: Alianza Editorial. American Statistical Association (2016). Guidelines for Assessment and Instruction in Statistics Education College Report 2016 (). GAISE College Report ASA Revision Committee Retrieved from http://www.amstat.org/education/gaise.

Area M. (2014). Alfabetización digital y competencias profesionales para la información y la comunicación. Organización y gestión educativa: Revista del Fórum Europeo de Administradores de la Educación, 22(1), 9-13.

Ares V. M. (1999). La prueba de significación de la "hipótesis cero" en las investigaciones por encuesta. Metodología de Encuestas, 1, 47-68

Berry D. A. (1995). Basic statistics: A Bayesian perspective (). Belmont: Wadsworth.

Díaz C., \& de la Fuente I. (2004). Controversias en el uso de la inferencia en la investigación experimental. Metodología de las Ciencias del Comportamiento, Volumen especial, 161-167.

Díaz C., \& Batanero C. (2006). ¿Cómo puede el méto do bayesiano contribuir a la investigación en psicología y educación? Paradígma, 27(2), 35-53.

Dienes Z. (2011). Bayesian versus orthodox statistics: Which side are you on? Perspectives on Psychological Science, 6(3), 274-290.

Edwards W., Lindman H., \& Savage L. J. (1963). Bayesian statistical inference for psychological research. Pshychological Review, 70, 193-242.

Egbo O. P., Chinwe R., Ikechukwu C., \& Onwumere J. U. (2011). Gender perception and attitude towards ELearning: A case of Business students, University of Nigeria. International Journal of Computer Application, 1, 135-148.

European Commission (2008). Mapping the maze: Getting more women to the top in research (). European Communities: Science, Economy and Society. Scientific Culture, and Gender Issues.

Falk R., \& Greenbaum C. W. (1995). Significance tests die hard: The amazing persistence of a probabilistic misconception. Theory and Psychology, 5(1), 75-98.

Fernández-Márquez E., Vázquez-Cano E., \& López Meneses E. (2016). Los mapas conceptuales multimedia en la educación universitaria: recursos para el aprendizaje significativo. Campus Virtuales, 5(1), 10-18.

Finch S., Cumming G., \& Thomason N. (2001). Reporting of statistical inference in the Journal of applied psychology: Little evidence of reform. Educational and Psychological Measurement, 61, 181-210.

Garbarino E., \& Strahilevitz M. (2004). Gender differences in the perceived risk of buying online and the effects of receiving a site recommendation. Journal of Business Research, 57, 768-775.

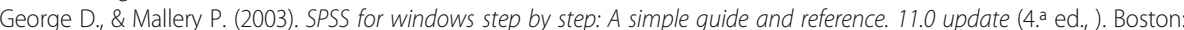
Allyn \& Bacon. 
Goswami A., \& Dutta S. (2016). Gender differences in technology usage. A literature Review. Open Journal of Business and Management, 4, 51-59 http://dx.doi.org/10.4236/ojbm.2016.41006.

Hager W. (2000). About some misconceptions and the discontent with statistical tests in psychology. Methods on Psychological Research, 5, 1 Retrieved from http://hbanaszak.mjr.uw.edu.pl/TempTxt/Hager_2000_About\%20some \%20misconceptions\%20and\%20the\%20discontent\%20with\%20statistical\%20tests\%20in\%20psychology.

Hupfer, M. E., \& Detlor, B. (2006). Gender and web information seeking: A self-concept orientation model. Journal of the Association for Information Science and Technology, 57, 105-115. doi: 10.1002/asi.20379

Islam A., Abdul Rahim N., Chee Liang A. T., \& Momtaz H. (2011). Effect of demographic factors on E-learning effectiveness in a higher learning institution in Malaysia. International Education Studies, 4, 112-122 http:// dx.doi.org/10.5539/ies.v4n1p112.

Jackson L. A., Ervin K. S., Gardner P. D., \& Ervin N. S. (2001). Gender and the Internet: Women communicating and men searching. Sex Roles: A Journal of Research, 44, 363-379 http://dx.doi.org/10.1023/A:1010937901821.

Jamil T., Ly A., Morey R. D., Love J., Marsman M., \& Wagenmakers E.-J. (2015). Default "Gunel and Dickey" Bayes factors for contingency tables. Behaviour Research Methods, 48, 1-16.

Jarosz A. F., \& Wiley J. (2014). What are the odds? A practical guide to computing and reporting Bayes factors. The Journal of Problem Solving, 7, 1 Article. 2. http://dx.doi.org/10.7771/1932-6246.1167.

Lecoutre B. (1996). Traitement statistique des données expérimentales: Des pratiques traditionnelles aux pratiques bayésiennes. Paris: CISIA.

Li N., \& Kirkup G. (2007). Gender and cultural differences in Internet use: A study of China and the UK. Computers and Education, 48, 301-317 http://dx.doi.org/10.1016/..compedu.2005.01.007.

Liaw S., \& Huang H. (2011). A study of investigating learners' attitudes toward E-learning. In Proceedings of the 5th International Conference on Distance Learning and Education (pp. 28-32).

Lindley D. V. (1993). The analysis of experimental data: The appretiation of tea and wine. Teaching Statistics, 15(1), $22-25$

Liu T., \& Sun H. (2012). Gender differences on information literacy of science and engineering undergraduates. International Journal of Modern Education and Computer Science, 4(2), 23-30.

Liu Z., \& Huang X. (2008). Gender differences in the online reading environment. Journal of Documentation, 64(4), 616-626.

Lubke G. H., \& Muthen B. (2004). Applying Multigroup confirmatory factor models for continuous outcomes to Likert scale data complicates meaningful group comparisons. Structural Equation Modeling, 11, 514-534.

Mazman S., \& Yasemin K. (2011). Gender differences in using social networks. TOJET: The Turkish Online Journal of Educational Technology, 10(2), 133-139.

Morey, R.D., \& Rouder, J.N. (2015). Bayes factor: Computation of Bayes factors for common designs. R package version 0 9.12-2. https://CRAN.R-project.org/package=BayesFactor

Nysveen H., Pedersen P., \& Thorbjørnsen H. (2005). Explaining intention to use mobile chat services: Moderating effects of gender. Journal of Consumer Marketing, 22, 247-256 http://dx.doi.org/10.1108/07363760510611671.

O'Hagan A., \& Forster J. (2004). Bayesian inference. Kendall's advanced Theory of statistics (). London: Arnold.

OCDE (2010a). Working paper 21st century skills and competences for new millennium learners in OECD countries. (EDU Working paper no. 41)

OCDE (2010b). PISA 2009 at a glance (). OECD Publishing http://dx.doi.org/10.1787/9789264095298-en.

Okazaki S., \& Renda dos Santos L. M. (2012). Understanding E-learning adoption in Brazil: Major determinants and gender effects. International Review of Research in Open and Distributed Learning, 13, 91-106.

Ong C., \& Lai J. Y. (2006). Gender differences in perceptions and relationships among dominants of E-learning acceptance. Computers in Human Behaviour, 22, 816-826 http://dx.doi.org/10.1016/j.chb.2004.03.006

Pruzek R. M. (1997). An introduction to bayesian inference and its applications. In L. L. Harlow, S. A. Mulaik, \& J. H. Steiger (Eds.), What if there were no significance tests? (pp. 287-318). Mahwah: Lawrence Erlbaum.

Rajagopal I., \& Bojin N. (2003). A gendered world: Students and instructional technologies. First Monday, 8, 1 Retrieved from http://firstmonday.org/article/viewArticle/1023/944

Raman A., Rozalina Khalid Y., \& Rizuan M. (2014). Usage of learning management system (Moodle) among postgraduate students: UTAUT model. Asian Social Science, 10, 186-195 http://dx.doi.org/10.5539/ass.v10n14p186.

Richards G., Magee C., \& Artino A. R. (2012). You can't fix by analysis what you've spoiled by design: Developing survey instruments and collecting validity evidence. Journal of Graduate Medical Education, 4(4), 407-410.

Rindskopf, D. M. (1997). Classical and bayesian approaches. En L. L. Harlow, S. A. Mulaik, \& J. H. Steiger. What if there were no significance tests? (319-334). Mahwah: Lawrence Erlbaum Associates.

Rouder J. N., \& Morey R. D. (2012). Default Bayes factors for model selection in regression. Multivariate Behavioral Research, 47, 877-903.

Rouder J. N., Speckman P. L., Sun D., Morey R. D., \& Iverson G. (2009). Bayesian t-tests for accepting and rejecting the null hypothesis. Psychonomic Bulletin \& Review, 16, 225-237.

Rozeboom, W. W. (1970). The fallacy of the null hypothesis significance test. In. D. E. Morrison, \& R. E. Henkel, The significance tests controversy: A reader (216-230). Chicago: Aldine.

Sevillano M. A. L., \& Vázquez-Cano E. (2015). The impact of digital mobile devices in higher education. Educational Technology \& Society, 18(1), 106-118.

Suri G., \& Sharma S. (2013). The impact of gender on attitude towards computer technology and E-learning: An exploratory study of Punjab university, India. International Journal of Engineering Research, 2, 132-136.

Tahira Jamil A., Morey R. D., Love J., Marsman M., \& Wagenmakers E. (2017). Default "Gunel and dickey" Bayes factors for contingency tables. Behavior Research Methods, 49(2), 638-652.

Tüfekçi Z. (2008). Gender, social capital and social network(ing) sites: Women bonding, men searching (). Boston: Annual meeting of the American Sociological Association. Sheraton Boston and the Boston Marriott Copley Place.

United Nations (2014). Measuring ICT and gender: An assessment (). New York and Geneva: United Nations Retrieved from http://unctad.org/en/PublicationsLibrary/webdtlstict2014d1_en.pdf.

Vázquez-Cano E. (2012). Mobile learning with twitter to improve linguistic competence at secondary schools. The New Educational Review, 29(3), 134-147. 
Vázquez-Cano, E. (2014). Mobile distance learning with Smartphones and apps in higher education. Educational Sciences: Theory \& Practice, 14(4), 1-16. DOl: 10.12738/est.2014.4.2012

Vázquez-Cano E., López Meneses E., \& Sáez López J. M. (2016). La imagen de los países a través de una didáctica digital ubicua. Un estudio de caso en México. Revista Mexicana de Investigación Educativa, 21(68), 17-44.

Vázquez-Cano E., Mengual-Andrés S., \& Roig-Vila R. (2015). Análisis lexicométrico de la especificidad de la escritura digital del adolescente en Whastapp. Revista de Lingüistica Teórica y Aplicada, 53(1), 83-105.

Venkatesh V., \& Morris M. G. (2000). Why Don't men ever stop to ask for directions? MIS Quarterly, 24, 115-139 http://dx. doi.org/10.2307/3250981

Venkatesh V., Morris M. G., Davis G., \& Davis F. D. (2003). User acceptance of information technology: Toward a unified view. MIS Quarterly, 27, 425-478.

Wagenmakers E. (2007). A practical solution to the pervasive problems of $p$ values. Psychonomic Bulletin and Review, 14(5), 779-804 http://dx.doi.org/10.3758/BF03194105

Wagenmakers E., Beek T. F., Rotteveel M., Gierholz A., Matzke D., Steingroever H., ... Pinto Y. (2015). Turning the hands of time again: A purely confirmatory replication study and a Bayesian analysis. Frontiers in Psychology, 6, 494 http:// dx.doi.org/10.3389/fpsyg.2015.00494.

Western B. (1999). Bayesian analysis for sociologists: An introduction. Sociological Methods \& Research, 28(1), 7-34.

Wetzels R., Matzke D., Lee M. D., Rouder J. N., Iverson G. J., \& Wagenmakers E. J. (2011). Statistical evidence inexperimental psychology: An empirical comparison using 855 t tests. Perspectives on Psychological Science, 6(3), 291-298 http://dx.doi.org/10.1177/1745691611406923.

Submit your manuscript to a SpringerOpen ${ }^{\circ}$ journal and benefit from:

- Convenient online submission

- Rigorous peer review

- Open access: articles freely available online

- High visibility within the field

Retaining the copyright to your article

Submit your next manuscript at $\gg$ springeropen.com 